\title{
Recepting Gender Thought in Mamaos Cianjur (CDA against Ceurik Rahwana and Tangis Anjani)
}

\author{
Barkah \\ Indonesian University of Education \\ barkahprapta1976@gmail.com
}

\begin{abstract}
Ceurik Rahwana and Tangis Anjani are part of Mamaos Cianjuran (a kind of opening poem), which is the oral tradition of song in West Java. Ceurik Rahwana and Tangis Anjani were chosen as study objects because of their unique gender. The study method uses critical discourse analysis. The results of the study were in the form of gender values from the local wisdom of Ceurik Rahwana and Tangis Anjani. The sympathies of this study concerning gender equality and gender balance (equilibrium), in essence, gender equality is not the same as a whole, but share the role of each other to glorify each other.
\end{abstract}

Keywords: Gender Thoughts, Mamaos Cianjuran, Oral Tradition

\section{INTRODUCTION}

Reference to become a good human being in this life, one of which comes from the value of religious beliefs or beliefs held. Another source of goodness comes from moral teachings, norms, and social ethics. Traditional communities with their natural lives uphold the values of local wisdom as a reference or source of goodness.

One of the values of local wisdom is thinking about gender. Gender conception is understood as the balance of roles between men and women who support and need each other. Ceurik Rahwana and Tangis Anjani are two opening songs of Cianjuran mamaos which are gender-based based on local wisdom. The song arrays are interesting to be used as material for thought, appointment, reception as an alternative to deep reflection on the concept of gender. Sibarani (2012) emphasized that proper gender management is one of the supports for the wisdom of the core culture (welfare). This means that when this conception of gender is addressed and managed properly, it will indirectly create prosperity.

We must understand gender as a balance in the distribution of roles fairly, but not equality of roles because by nature it cannot be equated. The division of roles of women and men who enter into a marriage agreement (mitsaqon gholido) in the Qur'an is likened to clothing that functions as a cover of genitalia. Both do not position one of them to be a dominant subordinate other. For this reason, there needs to be an alignment in understanding the public that gender is a fair division of roles between women and men so that there is no domination or subordination between the two. Gender understanding like this is classified in the theory of balance (equlibrium).

Mamaos Cianjuran with the title Ceurik Rahwana and Tangis Anjani, is a concrete example of gender awareness, from the local wisdom of Sundanese cultural wealth. Rahwana, an alengka king who initially dominated and subordinated his wife, attained gender awareness even though it was too late. However, we can make this a mirror as a material for deep reflection to accept gender from our local cultural wisdom. Local genuins in the Cianjuran mamaos cross the ages and carry a universal message.

The selection of the object of study of Ceurik Rahwana and Tangis Anjani is based on several reasons, including: 1) taking visionary and universal thoughts from the purity of local wisdom 
contained in the two songs, 2) raising the meaning and usefulness of the Cianjuran mamaos, and 3) the application of gender theory to the genre of Sundanese culture.

\section{METHOD}

The method used in studying mamaos Ceurik Rahwana and Tangis Anjani is a qualitative research method with a critical discourse analysis approach. As the steps for the study of gender ideology according to Darma (2009) as follows: (a) creative-critical reading of data sources; (b) identification of data, in this case coded data; (c) presentation of data that has identified a gender ideology which includes: gender profile and gender identity; (d) interpretation of meaning; (e) summarizing the meaning, and (f) the results of gender profile and gender identity, gender roles and gender relations, and types of gender ideology and gender injustice.

Mosse (2002), giving gender limits as a set of roles such as costumes and masks on stage in the theater, tells others that someone is feminine or masculine. Furthermore, (Budianta, 1998) states that the basic principles of gender in literature and gender ideology, there are three basic principles of gender, namely: (a) biological antideterminism, which removes the notion that biological differences (sex) can determine differences in attitudes, traits, and behavior, (b) perspectives that reject the essentialistic way of thinking that appears in the use of the terms nature and destiny that are often used in normative discourse to provide justifications that are considered sacred for differences that are actually constructed socioculturally, and (c) masculine ideas and feminine does not just appear, but a cultural product that has a long history.

\section{RESULTS}

Ceurik Rahwana and Tangis Anjani are lulugu songs (opening) in the Cianjuran mamaos which are local Sundanese urang genuins, taken from the Ramayana epic in the deceased Ravana part. Ceurik Rahwana was hummed by male mamaos interpreters and Tangis Anjani was hummed by female mamaos interpreters intermittently with intermittent pyrex, pyrex, elaborate and distilled glasses with madenda or sorog. Silence and solitude are characteristics of this song. The flute of the harp playing in harmony in the nyorog position, the lines also means sad. Gender ideology that can be captured by the writer in the following lines Sobirin (2003).

Bait I
Banondari anu lucu
Bojo akang anu geulis ... geuning
Kadieu sakeudeung heula
Akang rék méré pépéling
Bait II
Aduh enung anu ayu
Nu geulis pupujan ati ... geuning.
Aduh geulis ...akang pinasti
Arék ménta dihampura
Lahir tumeka ing batin

Bait I
The funny banondari

My beautiful wife

Come here just a little

I want to give advice

The verses I and II above contain the praise of a husband (Rahwana) when calling his wife (Banondari) as funny (funny), geulis (beautiful), pupujan ati (idol of the heart), ayu (beautiful), enung (dear), as it praises and glorifies the wife. In the next two lines there is the dominance of Rahwana's patriarchy over his wife Banondari, indicated by the sentences: kadieu sakeudeng heula (come here 
for a while) and Akang rék méré pépéling (I want to give advice). In the next array there are expressions of consciousness, honesty, and guilt from Rahwana to Banondari such as: ... akang pinasti (akang to death) and Arék ménta dihampura lahir tumekaning batin (want to apologize born to the mind).

\author{
Bait III \\ Kaduhung akang kaduhung \\ Kataji nu lain lain ... geuning \\ Kaiwat goda rancana \\ Kagémbang ku Sintawati ...aduh \\ Geuning kieu balukarna \\ Malindes balik ka diri
}

\author{
Sorry for regret \\ Tempted others \\ Interested in the temptation of stratagem \\ Lured by Sintawati \\ It ends like this \\ Befall yourself
}

The third stanza contains Rahwana's remorse for the fate that befell him. His lust made Rahwana exposed to disaster and ended perish. When read in the epic Ramayana actually Sintawati did not do hegemony of love towards Ravana, but Rahwana who really loved Sintawati. Rahwana perished in the hands of Sri Rama (Sintawati's husband) does not mean that Sri Rama's desire to kill Rahwana, but Rahwana's death occurred because Sri Rama wanted to free Sintawati. The author interprets Rahwana's death as a result of Rahwana being hegemonyed (controlled) by his own desires, dominating all nature, arrogance accompanied by arrogance, as if controlling the universe and entitled to all women he wants.

Bait IV
Banondari akang ampun
Rumasa geus nganyenyeri ... geuning ...
Salawasna dikakaya
Nyandung geus puluhan kali ... aduh ...
Maneh nu sabar tawekal
Doraka akang kabadi
Bait V
Ayeuna tepung panungtung
Jeung akang mo panggih deui ...
Akang menta dihampura
Kaawak maneh nu geulis... aduh
Poma ulah rek gagabah mun boga salaki
deui

\author{
Banondari forgive you \\ Admitting that it hurt you \\ Forever hurt \\ Polygamy dozens of times \\ You be patient \\ Kanda ungodly affected by doom
}

Verses IV and $V$ above show the release of Rahwana's hegemony over his wife (Banondari). There is Rahwana's confession before death that during his marriage to Banondari he did hegemony and subordination.

Anjani's tears were Banondari's answer to Ravana. This song is sung by a woman. We can also interpret this as the equality of roles between the juru mamaos pameget (male singer) and the juru mamaos istri (female singer), there is no dominance between the two. Below are the Tangis Anjani poems:

Bait I

Duh engkang rumruman kalbu

Pupujan lahir jeung batin, gusti...2X

$O$ dear heart idol

Aya naon pangeresa

The one born and mind

What is the king? 


$\begin{array}{ll}\text { Tara-tara tisasari, gusti...2X } & \text { Not like usual } \\ \text { Nyauran ragrag cisoca } & \text { Call in tears } \\ \text { Abdi mah saredih teuing } & \text { I feel very sad }\end{array}$

Tangis Anjani's first stanza contains lines that express the obedience, obedience, respect and loyalty of a Banondari to Ravana. Obedience, obedience, loyalty, and sincere affection (sincere) towards the husband shown by Banondari is a good mother figure (ideal) husband's dream. In the theory of Darma (2009) it can be said as an ideology of familialism.

Bait II

Pisanggem abdi kapungkur

Lilisan kalenggah gusti, engkang...2X

Ka salira engkang pisan

Ngaturanan temah wadi, engkang...2X

Mung engkang kalalanjoan

Ngajur napsu teu dihiding

Bait III

Duh engkang rumruman kalbu

Teu kiat abdi wawarti,engkang...2X

Asa tungkeb bumi alam

Kantun sumerahnya diri,engkang...2X

Kahiang Murba Wisesa

Takdir tumiba ka diri
I said first

I say to you king

Dear you brother

Set up

It's just too much

Indulgence in lust is not restricted

The second and third stanzas in Tangis Anjani above, show the gender balance (equilibrium) played by a wife. Banondari did that solely to love Ravana as her husband. Being imposed on Banondari glorifies her husband by calling gusti, does not mean equating with the Essence of God. There are some Banondari sorrows that are very profound when Rahwana wills, namely: 1) sad and regretting that Rahwana ignored his advice, Rahwana only realized when it was too late, 2) sad because Banondari would part with his beloved husband. Separation is always sad and painful, whatever the cause of the separation.

a. Gender Profile and Gender Identity

There are several Gender Profiles and Gender Identity that can be found in the song Ceurik Rahwana (CR) and Tangis Anjani (TA), namely:

1) Rahwana greatly praises and glorifies his wife;

2) there is Rahwana's domination of Banondari, domination in this section is patriarchal ideology;

3) Rahwana's death due to Ravana's hegemony (controlled) by his own lust;

4) there is the dominance of Ravana over the universe and all the women he wants;

5) near death, Rahwana admitted that during his marriage to Banondari, he carried out hegemony and subordination;

6) familialism gender ideology (obedience, obedience, loyalty, and sincere affection (sincere) towards the husband shown by Banondari is a good mother figure (ideal) husband's dream); 
7) shows the gender balance (equilibrium) played by a wife in this case Banondari. Banondari did that solely to love Ravana as her husband. Bertapa Banondari glorifies her husband by calling gusti, does not mean to equate with the Essence of God, but because of love and glorify Ravana as a husband and as a king. Banondari glorifies her husband by calling gusti, does not mean to equate with the Essence of God, but because of love and glorify Ravana as a husband and as a king.

\section{b. The Role of Gender and Gender Relations}

The role of Rahwana in $C R$ and $T A$ as the king and husband of Banondari. Judging from the role of king Rahwana as a very powerful and tyrannical king in another genre story that the writer understands Rahwana kidnapped Sinta his wife Sri Rama. From Rahwana's role as Banondari's husband is a husband who is highly praised, said language that contains seduction, although often hegemony Banondari in terms of Rahwana's desire to polygamy.

Banondari as the wife and consort of Rahwana is a woman who is good, obedient, obedient, loyal, and sincere affection (husband) towards her husband who is shown Banondari is a good mother figure (ideal) husband's dream. Banondari did that simply loving Rahwana as a husband. Banondari glorifies her husband by calling gusti, does not mean to equate with the Essence of God, but because of love and glorify her husband and king.

c. Types of Gender Ideology and Gender Injustice in $C R$ and $T A$ are as follows:

(1) patriarchal ideology; (2) general ideology, there is the dominance of Ravana over the universe and all the women he wants; (3) ideology of gender familialism (obedience, obedience, loyalty, and sincere affection (sincerity) towards the husband shown by Banondari is a good mother figure (ideal) husband's dream).

\section{CONCLUSIONS}

The gender phenomena above, contain meanings that can be interpreted and concluded. First, in certain cases Rahwana and Banondari are a married couple who admire and glorify each other. This is an ideal condition in building a household ark. There is gender equality and gender balance (equilibrium) from the conditions they build.

Second, hegemony and domination can be divided into Ravana's hegemony and domination over Banondari (his wife), also hegemony in the normal category as patriarchal ideology, as well as hegemony and domination of Rahwana's lust towards Ravana. Hegemony and domination of a person against others begins with a self that has been hegemony or dominated, even shackled by lust (lust and power) itself.

Third, the ideology of gender familialism (obedience, loyalty, and sincere affection (sincere) towards the husband shown by Banondari is a good mother figure (ideal) the husband's dream). Honestly seeing it from a man's point of view, it elevates the image and glory of a woman, maybe men in general crave women who are obedient, loyal, and sincere affection. Women who have such a character also need to think harder in choosing a comparable partner. Actions (behaviors) carried out on the basis and intentions of sincere worship, it is impossible to get lost.

Fourth, gender balance (equilibrium) which is played by a wife in terms of mutual reminding, we should remind each other especially tied to marriage or blood ties. In the Sundanese tradition philosophy kudu akur jeung batur sakasur, sadapur, sasumur, salembur (must be good with a wife and the neighbor), salawasna silih asah, silih asih, and silih asuh (forever educate each other, love each other, care for each other). 


\section{REFERENCES}

Budianta, M. (1998). Sastra dan Ideologi Gender. Horison Tahun XXXII (4), 6-13.

Darma, Y. A. (2009). Analisis Wacana Kritis. Bandung: Yrama Widya, 212.

Mosse, J. C. (2002). Gender dan Pembangunan (diterjemahkan oleh Hartian Silawati). Yogyakarta: Kerja sama Rifka Annisa Women's Crisis Centre dengan Penerbit Pustaka Pelajar, 3.

Sibarani, R. (2012). Kearifan Lokal: Hakikat, Peran, dan Metode Tradisi Lisan. Jakarta: Asosiasi Tradisi Lisan, 170.

Sobirin, M. (2003). Rumpaka Tembang Sunda: Mamaos. Bandung.

(C) 2020 by the authors. Submitted for possible open access publication under the terms and conditions of the Creative Commons Attribution (CC BY SA) license (https://creativecommons.org/licenses/by-sa/3.0/). 